\title{
PENERAPAN MODEL PEMBELAJARAN INKUIRI TERBIMBING UNTUK MENINGKATKAN RASA INGIN TAHU (CURIOSITY) SISWA KELAS X MIPA 2 SMA NEGERI 6 SURAKARTA TAHUN PELAJARAN 2015/2016
}

\section{IMPLEMENTATION OF GUIDED INQUIRY LEARNING MODEL TO ENHANCE STUDENT CURIOSITY AT GRADE X MIPA 2 CLASS OF SMA NEGERI 6 SURAKARTA ACADEMIC YEAR 2015/2016.}

\author{
CHOIRUNNISA LATIIFANI, YUDI RINANTO, MARJONO \\ Program Studi Pendidikan Biologi \\ Fakultas Keguruan dan Ilmu Pendidikan \\ Universitas Sebelas Maret \\ Jl. Ir. Sutami 36 A, Surakarta, 57126, Indonesia \\ *Corresponding Author: nisalatiifani@student.uns.ac.id \\ Manuscript received : 14 Juni 2016 Revision accepted: 15 Agustus 2016
}

\begin{abstract}
The research aimed to enhance student curiosity by implementation of guided inquiry learning model at grade X MIPA 2 SMA N 6 Surakarta academic year 2015/2016 amount of 30 student comprise of 18 male and 12 female. This research was a Classroom Action Research that performed within 3 cycles. Each cycle consisted of 4 steps; planning, action, observation, and reflection. Data were obtained by observation, test, interview, and documentation. Student's curiosity assessed by observation and questionnaire. The data were analyzed by qualitative descriptive technique. The result showed that the student's curiosity were increased in precycle, cycle I, cycle II, and cycle III. Student who actively ask increased from 15,33 $\%$ to $54 \%$. Student who paid attention to do experiment increased from 40,67\% to 80,67\%. Student who interested to do experiment increased from $24,00 \%$ to $60 \%$, and student who made a note and summarized increased from $37,33 \%$ to $54 \%$. Conclusion of the research is that implementation of Guided Inquiry Learning Model can enhance curiosity of student in X MIPA 2 SMA Negeri 6 Surakarta academic year 2015/2016.
\end{abstract}

Keywords: Curiosity, Guided Inquiry Learning

\section{PENDAHULUAN}

Pendidikan bertujuan untuk menumbuhkan rasa percaya diri siswa, membimbing siswa menjadi pelajar yang sukses, mengajak siswa berkontribusi dalam kegiatan sosial serta melayani masyarakat. Pendidikan dihadapkan pada tantangan abad 21 untuk menumbuhkan pribadi siswa dan mampu memenuhi tanggung jawab sosial. Pendidikan karakter tentang kualitas, nilai dan kapasitas untuk membuat pilihan bijak dalam kehidupan dan masyarakat berkembang dapat menghadapi tantangan abad 21. Kualitas karakter menggambarkan bagaimana seseorang berperilaku. Karakter yang sesuai dengan kebutuhan abad 21 meliputi perhatian, rasa ingin tahu, keberanian, ketahanan, etika dan kepemimpinan (Bialik, Bogan, Fadel \& Horvathova, 2015). Rasa ingin tahu sebagai salah satu karakter yang berhubungan dengan diri siswa sendiri dan dapat ditumbuhkan dalam proses belajar mengajar (Kemendiknas, 2010).
Hasil observasi pembelajaran biologi di kelas X MIPA SMA Negeri 6 Surakarta pada tahun pelajaran 2015/2016 menunjukkan bahwa siswa mendengarkan dan mencatat materi yang dijelaskan guru. Siswa diam saaat diberikan pertanyaan secara lisan meskipun jawaban dari pertanyaan ada di buku pegangan siswa. Siswa kurang antusias dalam melakukan pengamatan. Siswa kurang berinteraksi dengan siswa lain. Siswa kurang aktif dalam menyampaikan pendapat dan bertanya. Apersepsi pada awal pembelajaran belum mampu memicu rasa ingin tahu siswa mengenai pelajaran yang diberikan, akibatnya di awal pembelajaran siswa kurang bersemangat.

Hasil observasi lanjutan mengenai rasa ingin tahu siswa kelas $\mathrm{X}$ MIPA 2 SMA N 6 Surakarta yang berjumlah 30 siswa menunjukkan bahwa keaktifan dan keingintahuan dalam proses pembelajaran masih kurang. Berdasarkan hasil pengamatan, sebanyak 4 dari 30 siswa $(15,33 \%)$ yang aktif bertanya kepada guru, 12 dari 30 siswa 
$(40,67 \%)$ perhatian dalam melakukan pengamatan, 7 dari 30 siswa $(24,00 \%)$ yang antusias melakukan penyelidikan dan 11 dari 30 siswa $(37,33 \%)$ yang mencatat dan membuat rangkuman pada saat pembelajaran. Hasil observasi menunjukkan rasa ingin tahu siswa yang meliputi partisipasi aktif dalam pembelajaran, antusias dalam melakukan penyelidikan, perhatian dalam melakukan pengamatan dan berusaha memperoleh informasi baru tergolong rendah.

Rasa ingin tahu sebagai sumber motivasi internal yang menjadi pondasi dalam proses pembelajaran sains. Rasa ingin tahu dapat mengembangkan kemampuan membaca, mendengar, berpikir dan berkomunikasi untuk mengeksplorasi pengalaman yang diperoleh siswa. Siswa dapat memahami informasi yang diperoleh dengan baik dari membaca atau mendengar. Siswa yang memahami informasi dapat berpikir dengan baik. Hasil pemikiran siswa mendukung komunikasi yang baik (Binson, 2009). Rasa ingin tahu memiliki empat aspek yaitu aspek keingintahuan terhadap informasi dan pengetahuan (epistemic curiosity), aspek keingintahuan terhadap objek baru melalui pengamatan dengan indera (perceptual curiosity), aspek keingintahuan terhadap bagian spesifik atau mendalam dari sebuah pengetahuan (spesific curiosity) dan aspek keingintahuan untuk mengeksplorasi pengetahuan (diversive curiosity) (Rowson, 2012).

Rasa ingin tahu sangat penting dalam proses pembelajaran, seperti yang dinyatakan oleh Ardiyanto (2013) bahwa dengan rasa ingin tahu membuat siswa berpikir dan mengamati secara aktif. Siswa yang aktif dan memiliki rasa ingin tahu termotivasi untuk mempelajari lebih mendalam tentang sesuatu yang sebelumnya tidak diketahui sehingga mampu menimbulkan kepuasan dan menghilangkan rasa bosan untuk mengembangkan ilmunya. Siswa dapat mengembangkan ilmunya dengan memiliki keingintahuan terhadap materi yang sedang diajarkan (Puspitasari, Santoso, \& Muchsini, 2015).

Pembelajaran untuk merangsang rasa ingin tahu siswa dirancang dengan mengoptimalkan potensi yang dimiliki siswa untuk membantu siswa dalam mengkonstruksi pengetahuannya. Pembelajaran yang melibatkan siswa untuk aktif membangun pengetahuannya dapat dilaksanakan dengan model pembelajaran active learning. Salah satu model pembelajaran active learning adalah model pembelajaran inkuiri.
Inkuiri mengakomodasi proses bertanya dan mencari tahu jawaban terhadap pertanyaan ilmiah yang dilakukan siswa (Hartono, 2013). Inkuiri meliputi berbagai aktivitas seperti mengajukan pertanyaan, melakukan pengamatan, mengajukan pendapat, mempelajari buku dan informasi yang lain untuk melihat apa yang telah diketahui dari penemuan-peneman yang sudah terbukti. Cara yang dilakukan yaitu dengan mengumpulkan, menganalisis, mendeskripsikan data, menyusun jawaban, penjelasan dan memprediksi, serta mengkomunikasikan hasil penemuan (Sadeh dan Zion, 2012). Inkuiri terbagi menjadi empat tingkatan yaitu confirmation inquiry, structured inquiry, guided inquiry, dan open inquiry (Banchi dan Bell, 2008).

Inkuiri terbimbing merupakan cara belajar dalam mempersiapkan siswa dengan kemampuan dan kompetensi untuk memperdalam pengetahuan (Khulthau, 2010). Inkuiri terbimbing menuntut peran guru dalam menentukan topik penelitian yang akan dilakukan, mengembangkan pertanyaan, menentukan prosedur, membimbing siswa dalam menganalisis data (Wisudawati \& Sulistyowati, 2015). Inkuiri terbimbing efektif untuk mendorong keterlibatan dan memotivasi siswa dan membantu siswa mendapatkan pemahaman mendalam mengenai pembelajaran (Eggen \& Kauchak, 2012).

\section{METODE PENELITIAN}

Penelitian merupakan Penelitian Tindakan Kelas (PTK) yang bertujuan untuk meningkatkan rasa ingin tahu siswa kelas X MIPA 2 SMA Negeri 6 Surakarta Tahun Pelajaran 2015/2016 melalui penerapan model pembelajaran inkuiri terbimbing.

Prosedur yang digunakan pada penelitian mengikuti model yang dikembangkan oleh Kemmis dan Mc Taggart berupa model spiral (Arikunto, 2006). Model spiral merupakan model yang berbentuk spiral dan terdapat tahap kegiatan dalam satu siklus terdiri dari perencanaan, pelaksanaan, observasi, dan refleksi.

Penerapan model pembelajaran inkuiri terbimbing dilaksanakan dalam tiga siklus yaitu siklus I, siklus II, siklus III. Pada siklus I dilaksanakan sesuai dengan hasil analisis observasi prasiklus, siklus II dilaksanakan berdasrkan hasil analisis refleksi siklus I, dan siklus III dilaksanakan berdasarkan hasil refleksi siklus II. Sehingga 
penerapan model Inkuiri Terbimbing dapat meningkatkan rasa ingin tahu siswa.

\section{HASIL DAN PEMBAHASAN}

Hasil analisis aspek rasa ingin tahu disajikan melalui perbandingan persentase capaian rata-rata setiap aspek rasa ingin tahu siswa dari prasiklus hingga siklus III pada gambar 1.

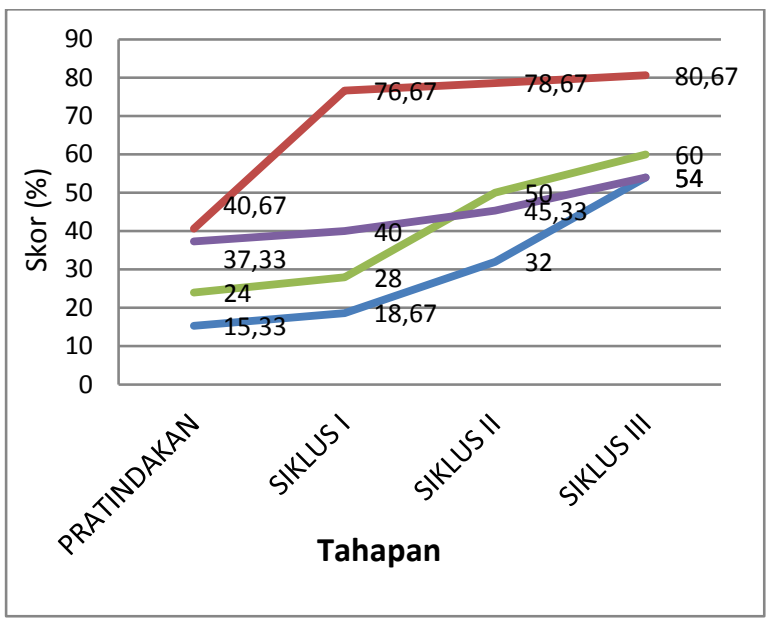

Keterangan:

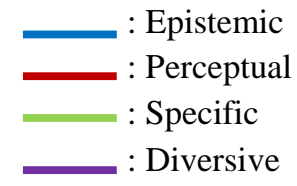

Gambar 1. Grafik Kenaikan Hasil Observasi Rasa Ingin Tahu Siswa pada Pratindakan, Siklus I, Siklus II, dan Siklus III

Gambar 1 menunjukkan bahwa terdapat pola secara umum dari keempat aspek rasa ingin tahu ada peningkatan dari Pratindakan hingga Siklus III. Aspek Perceptual Curiosity memiliki skor capaian rata-rata tertinggi dibandingkan aspek rasa ingin tahu yang lain. Aspek Perceptual Curiosity mengalami peningkatan yang signifikan dari pratindakan hingga Siklus I, pada Siklus I hingga Siklus III ada peningkatan tapi tidak terlalu signifikan. Aspek Epistemic Curiosity memiliki peningkatan skor capaian rata-rata terendah dari pratindakan hingga Siklus III dibandingkan aspek rasa ingin tahu yang lain. Pada pratindakan hingga Siklus III setiap aspek rasa ingin tahu mengalami peningkatan dan mencapai target. Perbandingan Hasil Observasi Rasa Ingin Tahu Siswa pada Pratindakan, Siklus I, Siklus II, dan Siklus III disajikan pada Tabel 1.
Tabel 1. Perbandingan Hasil Observasi Rasa Ingin Tahu Siswa pada Pratindakan, Siklus I, Siklus II, dan Siklus III

\begin{tabular}{ccccc}
\hline \multirow{2}{*}{ Aspek } & \multicolumn{4}{c}{ Tahapan (\%) } \\
\cline { 2 - 5 } Curiosity & Pratindakan & Siklus & Siklus & Siklus \\
& & I & II & III \\
\hline Epistemic & 15,33 & 18,67 & 32,00 & 54,00 \\
Perceptual & 40,67 & 76,67 & 78,67 & 80,67 \\
Specific & 24,00 & 28,00 & 50,00 & 60,00 \\
Diversive & 37,33 & 40,00 & 45,33 & 54,00 \\
\hline
\end{tabular}

Tabel 1 menunjukkan bahwa aspek Epistemic Curiosity mengalami peningkatan dari pratindakan hingga siklus III. Pada pratindakan memiliki nilai sebesar $15,33 \%$, siklus I meningkat menjadi $18,67 \%$, siklus II meningkat menjadi 32,00 $\%$, dan siklus III meningkat menjadi 54,00 \%.

Aspek Perceptual Curiosity mengalami peningkatan dari pratindakan hingga siklus III. Pada pratindakan memiliki nilai sebesar 40,67 \%, siklus I meningkat menjadi $76,67 \%$, siklus II meningkat menjadi 78,67 \%, dan siklus III meningkat menjadi $80,67 \%$.

Aspek Specific Curiosity mengalami peningkatan dari pratindakan hingga siklus III. Pada pratindakan memiliki nilai sebesar $24,00 \%$, siklus I meningkat menjadi $28,00 \%$, siklus II meningkat menjadi 50,00 \%, dan siklus III meningkat menjadi $60,00 \%$

Aspek Diversive Curiosity mengalami peningkatan dari pratindakan hingga siklus III. Pada pratindakan memiliki nilai sebesar 37,33 \%, siklus I meningkat menjadi $40,00 \%$, siklus II meningkat menjadi $45,33 \%$, dan siklus III meningkat menjadi $54,00 \%$.

Pada Siklus I terdapat aspek yang memiliki presentase paling rendah dan belum mencapai target. Aspek yang paling rendah yaitu Epistemic Curiosity (keingintahuan terhadap informasi dan pengetahuan). Siswa belum terbiasa berpartisipasi aktif untuk memperoleh informasi dari sebuah pengetahuan. Siswa pada saat proses pembelajaran lebih sering mengandalkan buku untuk menghafal dan mendengarkan penjelasan dari guru. Sebagai tindak lanjut untuk ketercapaian aspek, dilakukan Siklus II dengan materi interaksi komponen ekosistem.

Pelaksanaan Siklus II dilaksanakan berdasarkan refleksi Siklus I. Pada Siklus II aspek yang memiliki presentase paling rendah dan belum mencapai target masih sama, yaitu Epistemic Curiosity. Sebagai tindak lanjut untuk ketercapaian 
aspek, dilakukan Siklus III dengan materi aliran energi dalam ekosistem.

Pada Siklus III telah mengalami peningkatan pada tiap aspeknya. Tiap aspek rasa ingin tahu siswa meningkat mencapai target $52 \%$ dari presentase awal pratindakan. Ketercapaian presentase rasa ingin tahu siswa yang memiliki capaian tertinggi adalah Perceptual Curiosity (keingintahuan terhadap objek baru melalui pengamatan dengan indera).

Siswa yang memiliki konsep awal dapat dibimbing untuk membentuk kelompok dan berdiskusi, mencari informasi, mengumpulkan informasi, memperluas materi, berbagi informasi, dan mengevaluasi diskusi. Tahapan dalam pembelajaran inkuiri terbimbing merupakan kegiatan inkuiri yang dapat menumbuhkan rasa ingin tahu siswa. Inkuiri memiliki kelebihan dalam membangkitkan keingintahuan siswa sebagai bagian dari motivasi intrinsik (Pluck dan Helen, 2011). Inkuiri terbimbing terdiri dari sintaks inisiasi, seleksi, eksplorasi, formulasi, koleksi, presentasi dan penilaian. Aspek rasa ingin tahu siswa dalam penelitian ini adalah Epistemic Curiosity, Perceptual Curiosity, Specific Curiosity, dan Diversive Curiosity.

Inkuiri terbimbing meliputi berbagai aktivitas, seperti melakukan pengamatan, menjawab pertanyaan, mencari sumber, menganalisis, mengumpulkan data, menyusun jawaban, menjelaskan, memprediksi, dan mengkomunikasikan hasil penemuan. Hasil tindakan pada Siklus I, II, dan III menunjukkan bahwa model pembelajaran inkuiri terbimbing mampu meningkatkan rasa ingin tahu siswa. Proses pembelajaran dimulai dengan menghadirkan fenomena yang belum diketahui oleh siswa sehingga rasa ingin tahu tumbuh dalam diri siswa. Guru yang membimbing selama proses pembelajaran dapat mendorong siswa untuk berpikir. Pertanyaan guru sebagai salah satu cara menumbuhkan dan mendorong rasa ingin tahu siswa. Siswa dituntut menemukan jawaban dari pertanyaan dan membuat pertanyaan yang lebih mendalam melalui pertanyaan yang diajukan guru.

Inkuiri terbimbing berperan dalam membangun pembelajaran konstruktivisme yang menekankan pada keaktifan belajar siswa. Siswa dituntut membangun konsep awal dengan konsep yang diterima selama pembelajaran. Siswa membangun konsep dengan bantuan referensi, dan LKS. Guru tidak begitu saja memberikan pengetahuan kepada siswa, tetapi siswa yang harus aktif membangun pengetahuan dalam pikiran mereka.

Sintaks inisiasi adalah tahap guru menjelaskan materi yang akan dipelajari dengan membangun pikiran siswa. Guru menyajikan fenomena untuk memancing siswa mengajukan pertanyaan. Fenomena yang disajikan berupa video, pada siklus I mengenai komponen ekosistem, siklus II mengenai interaksi anemon dan ikan di laut, dan siklus III mengenai proses makan dimakan dalam ekosistem gurun. Siswa diminta mengamati kemudian menyusun pertanyaan untuk dilakukan penyelidikan.

Sintaks inisiasi mengacu pada aspek Perceptual Curiosity dengan melatih siswa memberi perhatian dalam menemukan informasi terhadap objek melalui pengamatan visual. Siswa diminta menggunakan berbagai sudut pandang dalam mengamati fenomena yang dihadirkan. Sintaks inisiasi juga mengacu pada Epistemic Curiosity dengan melatih siswa berpartisipasi aktif untuk memperoleh informasi dari sebuah pengetahuan. Siswa diminta membuat pertanyaan berupa rumusan masalah yang akan ditindaklanjuti dengan melakukan praktikum.

Sintaks seleksi adalah tahap siswa dibimbing guru untuk memilih pertanyaan yang telah diajukan siswa. Siswa memilih pertanyaan berupa rumusan masalah yang telah dibuat kemudian membuat hipotesis sebagai jawaban sementara yang relevan dari rumusan masalah. Tahap seleksi mengacu pada aspek Specific Curiosity melatih siswa untuk antusias dalam menyelidiki secara rinci sebuah pengetahuan. Siswa mengemukakan gagasan berupa hipotesis dan solusi dari rumusan masalah dengan mengenal lebih dalam bagian dari pengetahuan yang ada.

Sintaks inkuiri terbimbing mampu membuat siswa berpartisipasi aktif memperoleh informasi, perhatian dalam menemukan informasi, antusias menyelidiki secara rinci, dan berusaha keras memperoleh informasi lebih dari pengetahuan yang telah diketahui. Siwa lebih antusias dan senang karena siswa dapat mengeksplorasi rasa ingin tahu mereka dan mencari jawaban dari rasa ingin tahu tersebut. Komunikasi yang baik antara siswa dan guru, maupun antar siswa dapat menumbuhkan rasa ingin tahu dan mengisi kekurangan informasi. Kekurangan informasi dapat memancing siswa untuk bertanya. 
Berdasarkan analisis penelitian terkait dengan penerapan model pembelajaran inkuiri terbimbing terhadap rasa ingin tahu siswa, dapat disimpulkan bahwa penerapan model pembelajaran inkuiri terbimbing mampu meningkatkan rasa ingin tahu siswa kelas X MIPA 2 SMA Negeri 6 Surakarta Tahun Pelajaran 2015/2016.

\section{KESIMPULAN}

Kesimpulan penelitian bahwa model pembelajaran Inkuiri Terbimbing dapat meningkatkan rasa ingin tahu siswa kelas X MIPA 2 SMA Negeri 6 Surakarta Tahun Pelajaran 2015/2016. Rasa ingin tahu siswa meningkat secara signifikan dari pratindakan hingga siklus III sebesar $32,84 \%$.

\section{DAFTAR PUSTAKA}

Anwar, Herson. (2009). Penilaian Sikap Ilmiah dalam Pembelajaran Sains. Jurnal Pelangi Ilmu, 2 (5): 103-113

Ardiyanto, D. F. (2013). Pembelajaran Matematika dengan Pendekatan Konstektual Berbantuan Hands On Problem Solving untuk Meningkatkan Rasa Ingin Tahu dan Prestasi Belajar Siswa. Prosiding Universitas Yogyakarta, 175-184.

Arikunto, Suharsimi. (2006). Prosedur Penelitian. Jakarta: Rineka Cipta.

Aunurrahman. (2009). Belajar dan Pembelajaran. Bandung: Alfabeta.

Bialik, Maya., Bogan, Michael., Fadel, Charles \& Horvathova, Michaela. (2015). Character Education for the 21st Century: What Should Students Learn?. Switzerland: Montes Alti Educational Foundation.

Binson, Bussakom. (2009). Curiosity Based Learning (CBL) program. US-China Education Review, 12 (6): 13-22.

Branchi, H., \& Bell, R. (2008). The Many Levels of Inquiry. Journal Scicence and Children, 26-29.

Dimyati \& Mudjiono. (2007). Belajar dan Pembelajaran. Jakarta: Rineka Cipta.

Eggen, P \& D. Kauchak. (2012). Strategi dan Model Pembelajaran. Jakarta: PT Indeks.

Faizi, M. (2013). Ragam Metode Mengajarkan Eksakta pada Murid. Jogjakarta: DIVA Press.

Hamruni. (2012). Strategi Pembelajaran. Yogyakarta: Insan Madani.

Hartono, R. (2013). Ragam Model Mengajar yang Mudah Diterima Murid. Jogjakarta: DIVA Press.

Kang, Min Jeong., Hsu, M., Lrajbich, I.M., Lowenstein, G., Mcclure, S.M., Wang, J.T., Camerer, C.F. (2009). Epistemic Curiosity Activates Reward Circuitry and Enchances Memory. Social Science Research Network , 20 (8), 963-973.

Kuhlthau, Carol C., Maniotes, Leslie K., \& Caspari, Ann K. (2007). Guided Inquiry Learning in the 21st Century. London: Libraries Unlimited.
Kuhlthau, C. C. (2010). Guided Inquiry: School Libraries in the 21st Century. School Libraries Worldwide, 16 (1) $17-27$

Kurniawan, Yudha T. P. (2013). Character Building. Yogyakarta: Pro-U Media.

Kusumah, Wijaya \& Dwitagama D. (2012). Penelitian Tindakan Kelas. Jakarta: Indeks.

Mustari, Mohamad. (2014). Nilai Karakter: Refleksi untuk Pendidikan. Jakarta: Rajawali Press

Naim, Ngainun. (2012). Character Building: Optimalisasi Peran Pendidikan dalam Pengembangan Ilmu \& Pembentukan Karakter Bangsa. Jogjakarta: ArRuzz Media.

Paizaluddin \& Ermalinda. (2013). Penelitian Tindakan Kelas. Bandung: Alfabeta.

Pluck, Johnson, G. \&., Helen. (2011). Stimulating Curiosity to Enhance Learning. Education Science and Psychology, 2 (19)

Puspitasari, Mydha Tri., Santoso, Sigit., \& Muchsini, Binti. (2015). Upaya Meningkatkan Rasa Ingin Tahu dan Hasil Belajar Akuntansi Melalui Pembelajaran Kontekstual Dengan Metode Snowball Throwing Pada Siswa SMK Muhammadiyah 3 Gemolong. Jurnal "Tata Arta" UNS , 1 (1), 31-39.

Putra, Sitiatava Rizema. (2013). Desain Belajar Mengajar Kreatif Berbasis Sains. Jogjakarta: DIVA Press.

Putri, A.M., S. Khanafiyah \& H. Susanto. (2014). Penerapan Model Pembelajaran Kontekstual Dengan Pendekatan Snowball Throwing Untuk Mengembangkan Karakter Komunikatif Dan Rasa Ingin Tahu Siswa SMP. Unnes Physics Education Journal, 3 (1), 54-60.

Rowson, J. (2012). The Power of Curiosity. London: RSA Social Brain Centre.

Sadeh, I., \& Zion., M. (2012). Which Type of Inquiry Project Do High School Biology Student Prefer : Open or Guided?. Science Education, 42, 831848.

Sanjaya, Wina. (2009). Strategi Pembelajaran Berorientasi Standar Proses Pendidikan. Jakarta: Kencana Pernada Media Group.

Satori, Djam'an., \& Komariah, Aan. (2012). Metodologi Penelitian Kualitatif. Bandung: Alfabeta.

Setiyaningsih, Ika., Nugroho, Ary Susatyo., \& Prasetiyo. (2015). Pengaruh Penggunaan Modul Berbasis Masalah Dalam Pembelajaran Inquiry Terhadap Curiosity Dan Hasil Belajar Siswa Pokok Bahasan Sistem Koordinasi Kelas XI SMA N 1 Kayen. Prosiding Sains \& Entrepreneurship II, 333-341.

Silberman, Melvin. (2007). Active Learning: 101 Strategi Pembelajaran Aktif. Yogyakarta: Pustaka Insan Madani.

Simbolon, B.R. (2010). Paket Materi Pembelajaran Inkuiri Dalam Pendidikan Lingkungan Hidup Untuk Meningkatkan Perilaku Berwawasan Lingkungan Siswa SD di Jakarta, Vol.11, No.2. Universitas Kristen Jakarta.

Sudaryono, Margono, Gaguk., \& Rahayu, Wardani. (2013). Pengembangan Instrumen Penelitian Pendidikan. Yogyakarta: Graha Ilmu.

Sugiyono. (2013). Memahami Penelitian Kualitatif. Bandung: Alfabeta. 
BIO-PEDAGOGI 5(2): 1- 6, Oktober 2016

Suprihatiningrum, Jamil. (2013). Strategi Pembelajaran. Jogjakarta: Ar Ruzz Media.

Trianto. (2007). Model-Model Pembelajaran Inovatif Berorientasi Konstruktivistik. Jakarta: Prestasi Pustaka.

. (2012). Panduan Lengkap Penelitian Tindakan Kelas. Jakarta: Prestasi Pustaka.

Uno, Hamzah. B. (2007). Teori Motivasi dan Pengukurannya. Jakarta: Bumi Aksara.

Wahyuni, Endang Tri., Sugiyarto \& Sunarno, Widha. (2012). Pembelajaran Biologi Dengan Pendekatan Contextual Teaching and Learning Melalui Metode Observasi Laboratorium dan Lingkungan Ditinjau Dari Keingintahuan dan Kemandirian Belajar Siswa. Jurnal Inkuiri, 1(1), 1-9.

Wisudawati, Asih Widi \& Sulistyowati, Eka. (2015). Metodologi Pembelajaran IPA. Jakarta: Bumi Aksara.

Zion, Michael \& Sadeh, Irit. (2007). Curiosity and Open Inquiry Learning. $J B E, 41(4), 162-168$. 